\title{
The Bulgarian Composer Pancho Vladigerov - Psychological Origin of His Creative Personality
}

\author{
Krasimira Georgieva Fileva-Ruseva \\ Faculty of Musical Education, Academy of Music, Dance and Fine Arts; Plovdiv, Bulgaria
}

Email address:

krassyfilleva@abv.bg

To cite this article:

Krasimira Georgieva Fileva-Ruseva. The Bulgarian Composer Pancho Vladigerov - Psychological Origin of His Creative Personality. International Journal of Literature and Arts. Special Issue: Musical Theory, Psychology, Pedagogy and Performing.

Vol. 3, No. 5-1, 2015, pp. 1-13. doi: 10.11648/j.ijla.s.2015030501.11

\begin{abstract}
Pancho Vladigerov (1899-1978) is one of the most prominent Bulgarian composers. He has created 70 opuses of works with high aesthetic value and in a very extended range of genres. His works are performed all over the world, and every Bulgarian pianist has experienced his piano opuses. In the present study, I reveal the psychological prerequisites for his creative personality in the following order: typological characterization - evidence to classify the composer in a certain type, derived from his everyday life, from his performer's and pedagogical work and backed up by statements of his relatives, students and critics - the influence of the stated typological characterization on his artistic handwriting.
\end{abstract}

Keywords: Composer, Work, Opus, Pancho Vladigerov, Bulgarian Music

\section{Introduction}

Pancho Vladigerov (1899-1978) is one of the most prominent Bulgarian composers. He has created 70 opuses of compositions with high aesthetic value and in a very extended range of genres (among his works are: five concertos for piano and orchestra, two concertos for violin and orchestra; Concerto Fantasy for Violoncello and Orchestra, op. 35; the ballet "Legend of the Lake"; the opera "Tzar Kaloyan", "Symphonic Legend for Large Orchestra", op. 8, Symphony № 1, op. 33; Symphony № 2, "May symphony for String Orchestra", op. 44; the Heroic overture "The Ninth of September" for large orchestra, op. 45; the concert overture "Earth", op. 27; "Jewish Poem", op. 47; the dramatic poem "Song for Peace" for symphonic orchestra, op. 52; the symphonic suite for large orchestra "Lyulin Impressions", op. 63; orchestra suites, theatre music, works for chamber ensembles, solo opuses). Vladigerov is one of the founders of the Bulgarian national musical style and the native school of composers; a virtuoso pianist and conductor, who performed on stage in many European countries and left a significant trace in the cultural life of several European capitals. His works are performed all over the world, and every Bulgarian pianist has experienced his piano opuses. In the present study, I reveal the psychological prerequisites for his creative personality in the following order: typological characterization - evidence to classify the composer in a certain type, derived from his everyday life, from his performer's and pedagogical activity and backed up by statements of his relatives, students and critics - the influence of the stated typological characterization on his artistic handwriting. Admittedly, I do not deny that artistic preferences have a very important and irrevocable role in the formation of an author's style, but for the formation of the specific aesthetic inclinations and preferences, apart from social conditions, which are not the subject of the present study, the psychological characteristics of the creator are also of importance.

\section{Subject, Aims and Tasks of the Study}

The main goal of this study is to reveal the specific characteristics of the creative appearance of the composer Pancho Vladigerov, on the basis of his psychological characteristics.

The subject of the study is the characteristic features of the musical works, performer's specification and pedagogical style of the composer.

The object of my attention is the manifestations of the psychological qualities of Vladigerov in his musical activities and everyday life.

The specific tasks are to:

a) Prepare a characterization of the main psychic features 
of the tone artist.

b) Study the musical heritage of the composer.

c) Study the performer's style of the pianist Vladigerov.

d) Explore the available information about the pedagogical principles of the great Bulgarian musician.

e) Compare and summarize the obtained findings.

The instrumentarium for the study includes:

a) Analysis and summarization of the existing information about the life of the composer.

b) Formal-aesthetic and performer's analysis of the works of Vladigerov.

c) Critical analysis of the available records of performances by the Bulgarian virtuoso.

d) Study of the documentation about the pedagogic methods and aesthetic views of the composer.

e) Comparison of the published musicological analyses and critical articles about works of Vladigerov.

\section{The Creative Personality of Pancho Vladigerov}

\subsection{Temperament}

Since the composer is no longer among the living, I cannot assess his temperament with the Keirsey test, because it would not be possible to answer the 70 questions of the survey, used for diagnosis of the temperament. For that reason, I limited myself to define according to the four classical temperaments and analyze the manifestation in Vladigerov of the neurophysiologic traits, to which each of these four types is related. On the other hand, the specifics of the brain functioning of a creative person have the most direct relation to his artistic product. Because of this, I place specific focus on the neurophysiologic traits of the tone artist in the present study.

Pancho Vladigerov could be described as a sanguine. This, in neurophysiology, where the qualitative indicators of the states of activeness and inactiveness in the brain are accounted for, is most resembling the description of a strong, balanced, mobile type. In the interest of achieving greater detail and argumentation of this important for the artistic appearance characteristic, I will review its elements separately. The strong type is defined by intensiveness, saturation in the brain function of activeness and inactiveness Since these two states have temporal parameters - duration and dynamics (their intensiveness increases or decreases over time, or they pass one into the other) and since we can judge their saturation also by a certain result of them, they can be viewed as processes, too.

\subsubsection{Strong State of Activeness}

The strong processes of activeness in the brain are usually related to the speed of performing a specific action, with the tension and the scale of its deployment. The saturated states of inactiveness, surrounding the fields in the brain, where the activity of the brain is maintained, and limiting the spreading of the activeness to neighboring sectors (which would impede the performance of the activity), are related to the accuracy of the activity, the sustainability of the interest towards it, the duration of the concentration on one and the same object.

The great power of the activeness in the psychic activity of the composer is illustrated clearly by his enormous work capacity and productiveness. The variety of activities in the creative career of Vladigerov - he was a composer, conductor, concerting virtuoso pianist, successful accompanist, pedagogue (teacher in composing, piano, chamber music) proves not only his multi-dimensional talent, but also his ability to maintain simultaneously several bright areas of activeness in the brain sectors, responsible for each of these activities, i.e. for the immense power of the state of activeness. The incredible work capacity of the tone artist could be illustrated with a story, told by his biographer, Evgeni Pavlov: "In the home of Vladigerov, his friend, Dmitri Shostakovich, had come to visit, and our conversation led us to the Fourth Piano Concerto (at the time, it was the latest). Pancho sat at the grand piano and did not stand back up until he had played all four concertos, in the order of their numbers. He was playing the solo part, marking the orchestra, playing without removing the cigarette from his mouth, stopping only for just a little bit, only to lit up a new one or to take out his handkerchief, the ashes were scattering on his old work trousers.... and, after that, he did not stop, continuing to play also other orchestra works, following the musical score" [13, p. 20].

Indicative for the power of the processes of activeness is the bright impact, which such individuals have on others around them. Everywhere he went, Pancho Vladigerov brought with him his presence of illuminating cheerfullness and optimism, his sincere humour. Especially catching was his influence on the audience as a performer, often commented by critics, as well. About a concerto of the Vladigerov brothers (Pancho Vladigerov had a twin brother Lyuben - a violinist) in Plovdiv, performed in 1919, Tz. Tzankov wrote: "... that wild, frantic passion, with which Vladigerov captivates and holds in a high state of tension even the most incapable of artistic immersion listener. It is as if he is grasping flaming sounds with both of his hands and throwing them with a genius swoop into the soul of the listener" [quote from 9, p. 46]. A concerto by Pancho Vladigerov in Vienna from the 3th March, 1947, was described by Joseph Marx including the following words: "with captivating, blazing virtuosity" [quote from 9, p. 167]. The performer's style, marked by the powerful impact on the listeners, shows clearly the incredible power of activeness in the psychic activity of the tone sculptor.

Vladigerov had a high emotional influence also on the soloists, whom he was accompanying. This is clearly proven by the reviews and appreciations, like the shared by the violinist Boyan Lechev in an article of his [11, p. 15]: "I could never forget our first encounter, the first clash with the musical tempest of Vladigerov. Devoid of the ability to think or reason, I was listening, captivated, how, under the fingers of the author, the grand piano was transformed and took on 
the power and the colouring of a large symphonic orchestra".

His bright charisma was remarked also by his students, as well as the researchers of his opuses. Significant for the character of his influence is the repetition of words like "blazing" and "energy" in the statements by his students and critics about the artistic image and the works of Vladigerov, for example: Anton Dikov (pianists, student of Vladigerov): "At 75, Pancho Vladigerov is bright and flaming with energy" [19, p. 16]; Pravda Goranova (musicologist): "The finals of his concertos are paintings of folk celebrations, sparkling, full of radiance and energy, in which vortices the storm of the dance..." [6, p. 36]

The power of the processes of activeness is made evident also by his great productivity as a composer, which I already noted.

In the tone works of Vladigerov, the power of activeness finds expression in his large-scale works with bright culminations, filled with tension. "Song for Peace" has even been criticized for its immense dramatism [9]. Exhibitive for the emotional saturation of his works is an article in the newspaper "Literary Voice", issue 25, in which Nikolay Fol comments the "live" recording of "Bulgarian Suite, op. 21" on a gramophone record in Berlin: "The orchestra thunders. Triumphant dynamite music. Dynamite! There, it is going to explode, to pour over the world.

" B-r-rrrr... Barbarian!"

"Genius!"

A German:

"This is something absolutely original! Something terrible! Something genius!" [quote from 3, p. 28].

The power of the activeness, expressed brightly in the works of Vladigerov, has been very accurately captured by the musical critic Ivan Kamburov: "With a technical scope, reaching geniality, he creates music of the highest rank - and still, it is as if the tonal means of expression and the volume of the keyboard are insufficient for the amplitude of his flight" [quote from 9, p. 100]. Such flattering feedback the composer received not just from the Bulgarian press. In harmony with the above quotation, but regarding a different opus, is the opinion of the Austrian critic Alfred Rosenzweig in the newspaper "Der Wiener Tag" from 13 of November 1933 [quote from 9, p. 119]: "... Vladigerov performed for the first time his second concerto for piano - a piece of art, overflowing in all the colors of the new romantic orchestral luster, with vitality, surpassing all limits, which almost does not give way for lyrical moments of tranquility."

The powerful processes of activeness are clearly visible in one method, so often found in the piano works of Vladigerov, so as to be accepted as only a portrayal of a specific musical image - it is the gradual acceleration in the tempo of a piece in an irregular meter, while at a certain moment, the irregularity is overcome and the piece continues in a regular meter. If in "Horo Dance of the Master" we can assume that the dance (horo) becomes more impetuous by the end, and that the acceleration and the transition to a regular meter illustrate exactly that (the work begins in a meter of ${ }_{8}^{7}$ and, after multiple "switches" between ${ }_{8}^{7}$ and ${ }_{8}^{5}$, the regular ${ }_{4}^{2}$ meter is established), the same event is hard to explain from this position in regards to "Rhythmic Movement", where, as expected from a piece with that title, the metro-rhythmic organization, set at the beginning, should remain unchanged until the end. It is more probable such a development to be an immediate expression of the temperament of the composer and more specifically of the prevailing processes of activeness overcoming the restricting power of the processes of inactiveness.

In the pieces, it is easy to find a plenteous harmony, with many voices, added at specific moments, with many foreign tones, which to a certain degree could be explained with irradiation, with a particular expanse of the activeness.

It could not be claimed that the processes of activeness absolutely and always prevail in power in the psychic activity of Vladigerov and in that sense the composer could be defined as a representative of the balanced type. Such beautiful lyrical images, as "Lullaby", confirm the efficient work of the processes of "inactiveness".

\subsubsection{Power of the State "Inactiveness"}

The incredible concentration and self-discipline of Vladigerov are a clear proof of the powerful processes of inactiveness in him. In that sense, an accurate indirect characterization of his strong state of inactiveness, has been made by the composer V. Kazandzhiev, a student of Vladigerov: "He demonstrated to us in a brilliant way the required components of the great creator - will, perseverance, elaboration of details to the greatest extent, self-criticism and honesty" [13, p. 18].

The author's performances of the complex works of art, especially of the concertos for piano and orchestra, characteristic of which is also the great accuracy and preciseness of movements, demonstrate the power of inactiveness in the psychic activity of Vladigerov.

The way, in which the composer wrote down his musical scores, is very accurate, clear and perspicuous. Comments in this sense have also been made by his student, the composer Konstantin Iliev [9].

A declaration for the power of the processes of inactiveness in Vladigerov is the presence in his works of a large number of lyrical miniatures, of a fine ability of observation and sense of distinctiveness in the creation of the rich and accurately individualized musical personages. This sense is heightened by the powerful processes of inactiveness, limiting the spreading of the activeness, i.e. focusing the attention on the details of a small object. The softness and serenity of the short lyrical works, the rich nuancing of one and the same character portrayed is an expression of powerful processes of inactiveness. "Song" from "Bulgarian Suite", op. 21 (Figure № 1) has been described by his son, Al. Vladigerov as "... one of the most heartfelt pages in the works of Vladigerov..." [13, p. 34]. 


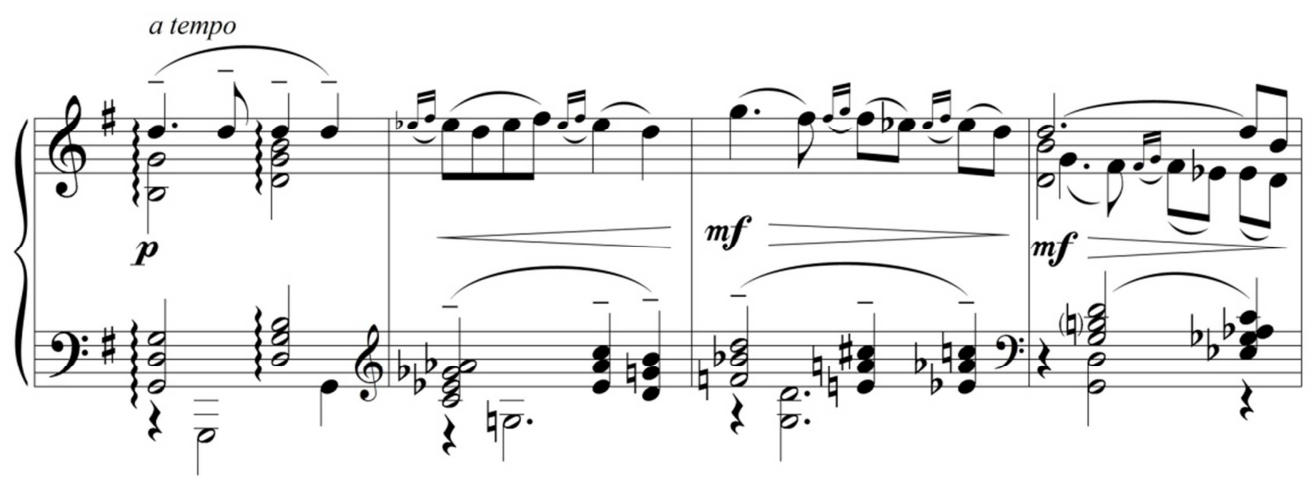

Figure № 1. "Song” from "Bulgarian Suite", op. 21, bars 21-24

The sense of distinctiveness is expressed also in the accurate understanding of the nationally specific features of music. This is shown clearly by the success in the corresponding countries of works like "Swedish Dance" from the music of the piece "A Dream Play" by Strindberg; "Four Romanian Symphonic Dances", op. 38; "Two Romanian Symphonic Sketches", op. 39; the popularity of "Jewish Poem", op. 47 [9].

In the musical art, the variation, the maintaining of the attention on a single object (the theme), its sequential development, enrichment, clarification, is associated with a powerful state of inactiveness. In regards to "Toccata", the researcher Pencho Stoyanov wrote: "The overall picture in Toccata, op. 36, would be incomplete and inaccurate without establishing the acting variation processes. They are powerful stimuli for the development of the thematic material and one of the main means, securing the overcoming of its resistance in the key moments. Similar variation processes, but with a larger amplitude of action, are present also in the "Paraphrases", op. 18" [14, p. 13].

For Pancho Vladigerov, the bright processes of inactiveness are a reason also for the non-acceptance of some phenomena in music, different from his way of expression through tones, for a certain inertness in tastes. On this same basis, as well, are his critiques, directed towards works of Ivan Spasov and Konstantin Iliev.

\subsubsection{Balance of the States of Activeness and Inactiveness}

Of the balance between the main states of the brain of the prominent composer, speaks also the following fact, related by his biographer - when Vladigerov stumbled upon some of his most talented students imitating his characteristic way of speaking, he, instead of showing irritation (typical for the strong unbalanced type, in whom the processes of activeness significantly prevail), or being offended and segregated (typical for the weak, unsure of himself type), he said: "Since you ar-r-r-r-r-r-e imitating so funnily how I speak, let's see can you imitate how I wr-r-r-r-rite?" [9, p. 292] and he gave his students the task of composing in one week seven minuets in his style. The calm certainty, the timely and adroit pedagogical improvisation, with the help of which he easily turned the embarrassing situation into an useful one, show for a balanced, quickly and accurately reacting teacher, sure of himself, bearing the self-confidence of an established author, who is capable of forgiving the liberties of the younger.

In his works, his balance is manifested in the clear, structured form, in the immediacy of the expression, in the multi-variety of the opuses - the presence of a large number of works, saturated with energy, tension, as well as the discerning lyrical pieces, and he reveals his mastery in all of them. The balance between the state of activeness and inactiveness has been accurately grasped by the musicologist Pravda Goranova: "... The two imagery spheres of the music of Vladigerov - the untamable energy, the overflowing exuberance and the sultry temperament on one side, and the light poetry, the touching lyric and the soft elegy - on the other - even though contrasting, are deeply related, connected. They are brought together by the optimistic world-view of the author, his tendency to reflect the infinite and everlasting beauty of life" [6, p. 36].

\subsubsection{Agility of the States of Activity and Inactivity}

The agility, the ease of transition of the states of activeness and inactiveness one into another, usually is associated with the easy shift from one activity to another, with tangible changes in the emotional nuances, achieved in a very short time, as well as with adaptivity.

The agility of the states in Vladigerov is "visible" even in the musical score of his works. In the piano works, instructions by the author are found for huge dynamic changes within a very short period of time (Figure № 2).

The flexibility is illustrated also by the prescriptions for frequent modifications of the tempo within the framework of a single play.

Characteristic of the performer's style of Vladigerov also are recurrent large agogic deviations, large and fast dynamic gradations, sudden "bursts" and drops in the dynamics subito forte and subito piano. Playing his works, he adheres accurately to all the rules, which he had left for his performers. These quick changes in the tempo and the thickness of the sound undoubtedly characterize a piano player with a great flexibility of the states of activeness and inactiveness.

For the great flexibility of the processes in Vladigerov, indicative is also his image as an accompanist. The violinist Boyan Lechev said: "He adapted to the requirements of his partner with a cat-like agility and quick-wittedness" [11, p. $15]$. 
Concerning the works of Pancho Vladigerov, the agility has been successfully registered by the musicologist $P$. Stoyanov: "The varied and colorful musical language of
Vladigerov easily adapts to the different structural conditions in the miniature or in the large-scale form" [14, p. 15].

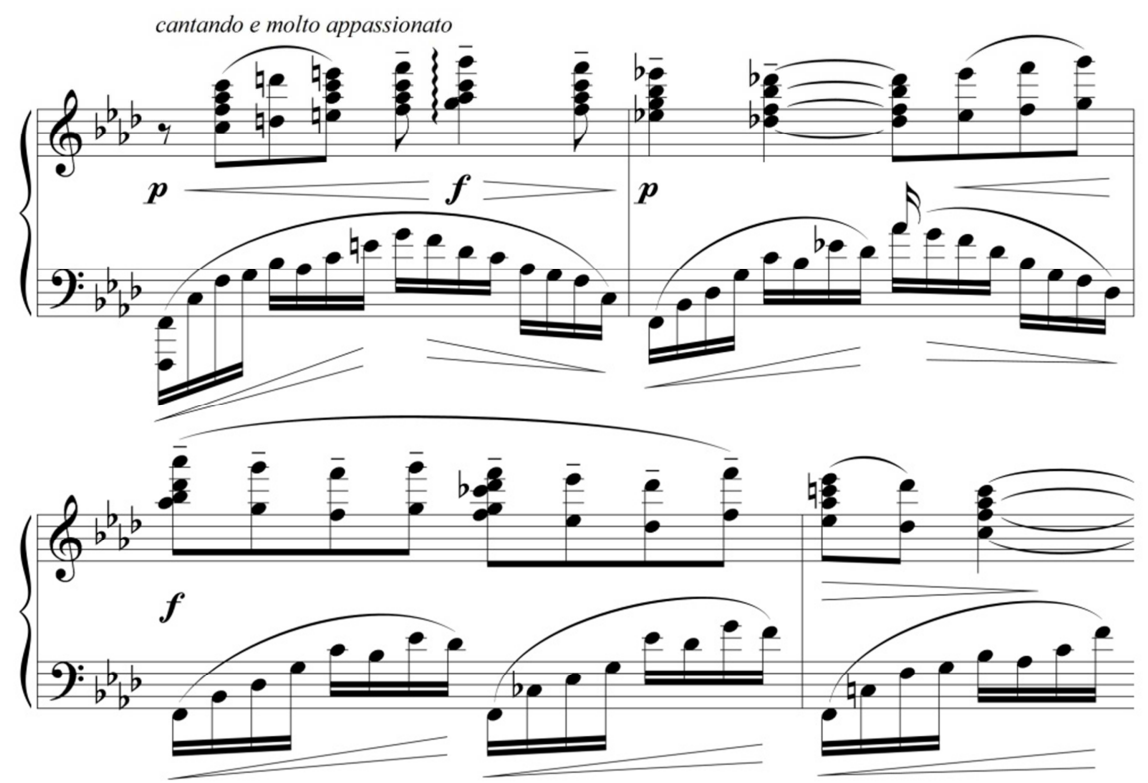

Figure № 2. "Prelude", op. 15, bars 6 -9.

In support of the statement that the neural activity of Vladigerov is characterized by great agility is also the fact that the culminations of some of his works are very manifold, heterogeneous in character. To illustrate that, I will present the culmination of "Autumn Elegy", op. 15. In this work of art, the peak moment is continuously and gradually preluded. After bar 11, the musical material transitions to a lower register. In order to clarify a possible analogy with a change in the colouring, I will invoke some physiological mechanisms of the perception of light and pitch of the sound. Light is a necessary external condition for the appearance of visual sensations. They reach the corresponding brain sectors, which react to light with activeness, and to darkness - with inactiveness. The stronger luminosity gives way for more frequent changes of stimuli (pictures of the surrounding world). This has a toning effect - contributes for a greater activity of the occupied with information processing brain cells. The higher sound frequencies have greater number of fluctuations for a unit of time, in comparison to the lower ones; this is reflected by the perceiver through more frequent changes between the states activeness and inactiveness. This means that the "cells, reacting to the higher sounds have systematic rest more often, which assures their greater activeness when perceiving" [2, p. 60]. The similarity in the work of the visual and audio analyzers is a possible reason for the appearance between them of a reflex of relation, creating the analogy high sound - light, low sound - darkness. This makes it possible for the transition to a lower register to be associated with darkening, provided that all the other means of expression are not subject to a significant change.

In the episode from bar 15, a functionality can be sensed, but the composer variegates his harmonic language with secondary third and fourth chords, with many foreign tones and alterations, which somewhat softens the weight and creates an impression of colorfulness. The structure from bars 23 - 30 represents a variant of the one from bars $15-23$, but located one octave higher and enriched with many ornaments, by which the diapason of the melody is significantly expanded, while the melodic graphic receives new undulant details with large amplitude. When the culmination is reached - in bar 30 - it turns out that the scale, used in the melody, as well as in the accompaniment, is a whole tone gamma (Figure № 3).

The harmony is comprised of parallel augmented triads, while the two different from them sound complexes include all the degrees of the whole tone sound line. This means that in neither texture plane in this first and most bright element of the culmination not a single half-tone appears, any kind of possible aggravation is excluded, everything, that bears tension. Even the end of the melodic motive (the beginning of bar 31) does not sound as a resolution, but as an unexpected appearance of c moll. What is more - the first element of the culmination is not developed evenly on all registers, while, with the exception of $\mathrm{G}_{1}$ octave, held with a pedal - $G$ is concentrated significantly more in a higher register. Given the fact that the language of expression is notably different from the one in the rest of the sound texture, this change cannot mean only a change in the illumination of the same observed object. In that case, the explanation should be sought elsewhere. The warm colors bear tension and the absence of tension is typical for the cold colors. This, combined with the absence in the musical text of half-tones, which would cause tension and would "increase the emotional degree", gives not only the basis for the 
assumption, but also guides the listeners to the image of colors in the cold spectrum. The second element of the culmination (bars 31 - 32) has a different character - presents a continuous retention on the tonic and a Neapolitan chord in c moll. In addition to the clarified functionality, in this element of the culmination, a thicker (three-voice) texture plane also appears, in the middle and lower register, i.e. the presence of a new clear change in the colors. The third element (bars 33 - 35) is different from the first two - it consists of unusual harmonic moves, accompanying the mainly chromatic descending intonations in the melody. A quick decrease in the dynamic follows. This heterogeneous structure of the culmination shows that it is not a common bright dramatic moment, whose tension is based on chords of the dominant function. Here are found three clearly distinguished, contrasting one with the other by their harmonic organization, elements, which supports the statement that this is a culmination of a work with a depicting character, and the obvious contrast between the three elements is the comparison of three bright, but notably different colour spots. Exactly the impact of their contrast (of the fast and sudden changes in the sounding, created by an author with very flexible processes of activeness and inactiveness), is at the basis of the emotional power of the culmination.

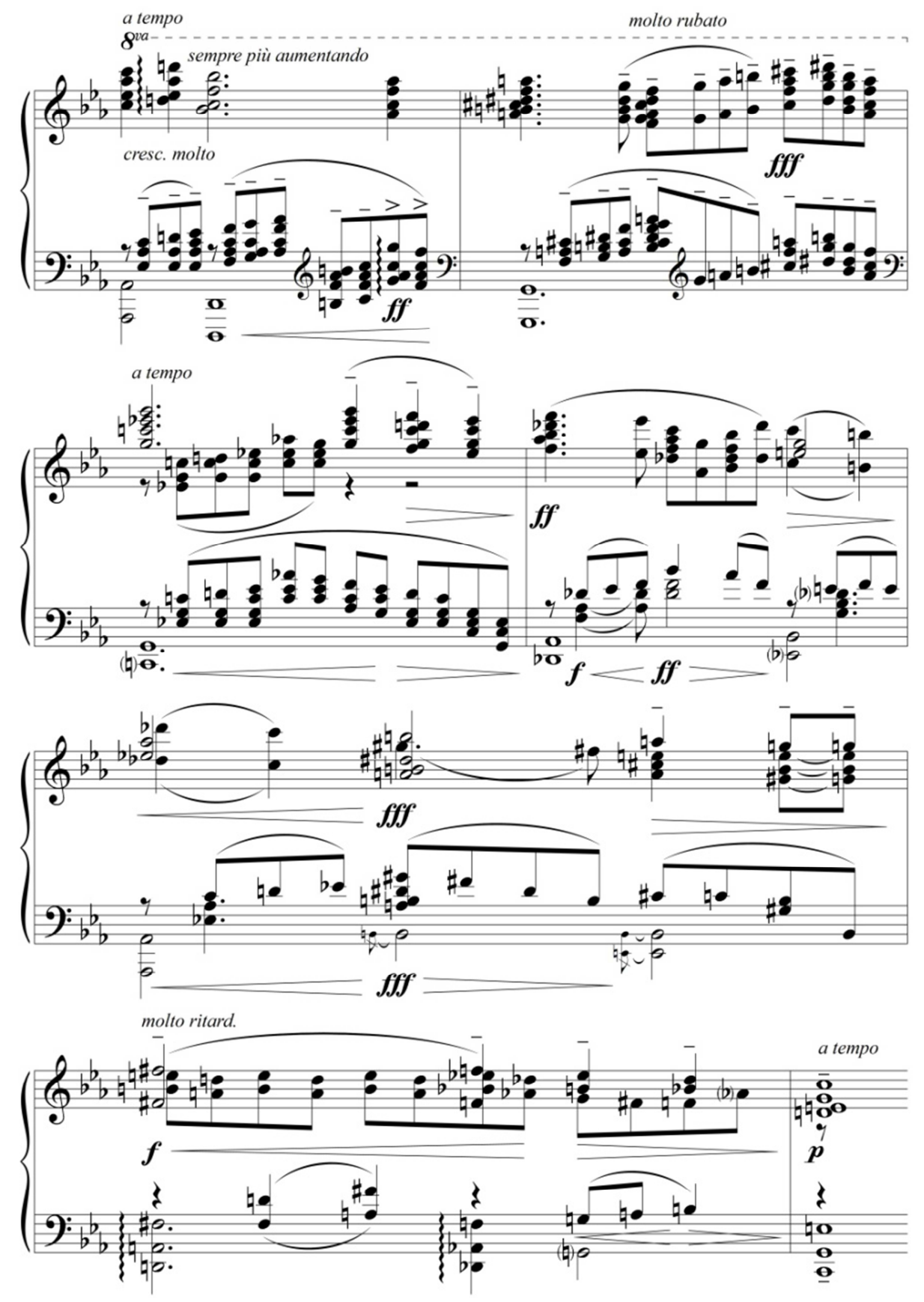

Figure № 3. “Autumn Elegy” op. 15, b. 29-35. 


\subsection{Extraversion}

Pancho Vladigerov was an extravert (a term of K. Jung). He communicated with ease with different people, maintained heartfelt and warm relationships with his students even after the end of their education; he was a friend of some of the greatest composers, performers and cultural figures of his time [9]. Among his friends were the Russian composers D. Shostakovich, T. Khrennikov, A. Khachaturian, the Swedish composer Kurt Atterberg, the Russian violinist D. Oistrakh, the Russian conductor E. Svetlanov, the German theatric director Max Reinhardt, the Bulgarian poets Dora Gabe, Nikolay Liliev, and many others. One wall of the work office in the home of Vladigerov - the room was also used as a guest room [9, p. 178-179] - was filled with signed photographs of his numerous famous acquaintances and friends from different countries. The composer Alexandar Tanev described his meetings with Vladigerov specifically in that environment, in the following way: "The nervousness I felt in that environment, however, was immediately overcome by his complete sincerity, by his openness; I saw how vivid he was, how he loved to joke and laugh, and how the barrier, created by his enormous authority, melted"[18, p. 22].

The extravert Vladigerov preferred spoken language, i.e. the live contact with people, more than the written word, where the interlocutor was a hypothetical one.

To convince ourselves that the composer Pancho Vladigerov was an extravert, it is enough to listen through the piano piece "Humoresque", op. 15. The directly instilled humor, pouring literally from each tone, the straight communication with the senses of the perceiver, leaving not one hidden nuance of the sincere joy, to which you give in wholly and without reserve; they, generously spreading the carelessness and merriment, overpower you with their imperious spontaneity and cannot leave even a single listener cold-blooded, could not have been created by an introvert (Figure № 4).
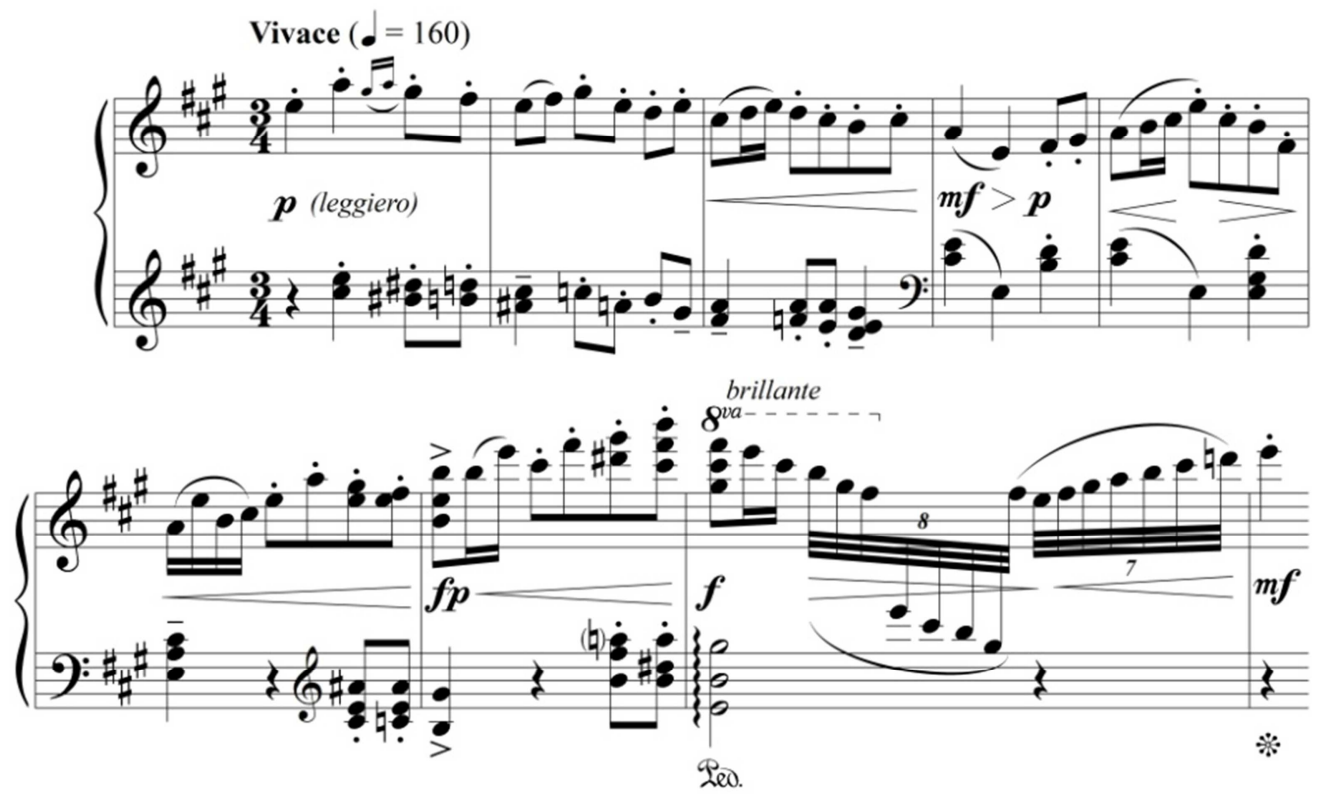

Figure № 4. "Humoresque", op. 15, bars 1-9.

The composer Ivan Spasov has grasped a clear difference between the music of two of the Bulgarian composersclassics - the extravert Pancho Vladigerov and the introvert Lyubomir Pipkov: "I would like to make my own, perfunctory parallel between Vladigerov and Pipkov. In the first one, the thought is developed in width, while in Pipkov, there is a greater strictness and explicitness; the music of Vladigerov is like a calm, vastly spread river, while for Pipkov, the shores are clearly outlined, the power is embedded in depth (the italics are by me - K.F.); Vladigerov is lyrical-epic, Pipkov - lyrical-dramatic" [1, p. 27].

\subsection{Imagination}

According to Isaac Roset [12], the two main mechanisms of imaginations are anaxiomatization and higher assessment. We speak of anaxiomatization, when for a certain task, which has no solution, instead of giving up on solving it, which logically would be the right approach, one of the given conditions is ignored, in order to find a solution. The other main mechanism - higher assessment - represents transiting a solution, idea, thought, which has been adequate for specific conditions and positively assessed, from the conditions, needed for its appearance, to new, uncharacteristic or even conflicting to it conditions.

The higher assessment has an artistic manifestation also in Vladigerov. Here, the position of an idea, which is "implanted" in an unusual environment, is taken by already established melodic structures - the Bulgarian folk songs.

The unusual for the folk song environment consists of: 
- Classical musical instruments (whose timbers are clearly different from those of Bulgarian musical folk instruments);

- The academic voice, with the principally different training from the ones of Bulgarian folk singers, and from there - with a very different sounding;

- The thick multivoice and multicolour texture with a varied accompaniment (typical for the national musical folklore is the single-voice singing. Two-voice songs are found significantly more rarely and have a varied high voice and a droning low one, or there is movement in the lower voice, but it most often represents a doubling of the higher voice on a harmonic second).

When combining intonations and rhythms from folklore music in a new way, in order to construct the texture of the author's work, Vladigerov shows ingenuity, combinativeness, a sense of distinctiveness and of the aesthetic acceptability of intermixing.

To a degree, as a result of the higher assessment, the composer often creates also a transcription of a great part of his own works, while many of his most loved works have been adapted many times and are performed by different ensembles. Such is the example with "Vardar Rhapsody", which in its original is for violin and piano, has 6 transcriptions by the author (for piano, for piano in 4 hands, for two pianos, for symphonic orchestra, for violin and orchestra, for two violins).

A manifestation of a higher assessment is also the method of the composer, as well as of other tone creators of his generation, to inweave meters, rhythmic groups, intonations, typical of the Bulgarian musical folklore, in author's melodies, which gives them a marked national sounding.

The contribution of Pancho Vladigerov to the creation of a national composer's style is characterized not by denial and rejection of the achievements of the Bulgarian tone creators, who have worked before him, i.e. not by a literarily manifested anaxiomatization, but much more through development, enrichment of the valuable in their ideas and practices, combining them also with some new methods of composing and sound expression, adopted during the education of the author in Western Europe (i.e. it is based much more on the mechanism higher assessment). This has been successfully "grasped" in one statement by the composer Lazar Nikolov, a student of Vladigerov: "It made an impression on me that a creative idea connection exists more between the music of Panayot Pipkov and Pancho Vladigerov, than between the music of Pan. Pipkov and Lyub. Pipkov, even though they are father and a son" [13, p. 18]. Lazar Nikolov found also that the music of Vladigerov is a ".. natural consequence of the creative tendencies of our first composers [same source - 13, p. 18]. A manifestation of anaxiomatization could be found in Vladigerov's approach to multivoiceness: the tone creator rejected the existing until then practice to, when elaborating folk songs, or citing them in an author's work, harmonize them with the means of the classic major-minor system and the chord structure of the multivioce, which impeded the expression of the national features and the specific beauty of the melody. Instead, the composer built his multivoice texture without violating the embedded in the song modal structure (which was often a medieval mode or a modal structure with an augmented second), took into account the susceptibility of our folk song to polyphonic development and used a very diversified harmonic language, in which the phonism of the assonances became of great importance. In this way, the folk melody not only was not depersonalized, but the national specific features were accentuated.

\subsection{Extremely Artistic Type}

The noted dominance of the abstract-logical thinking over the specific-imaginative suggests that a certain individual belongs to the thinking type. On the other hand, the distinguished preference for specific-imaginative thinking suggests that the individual should be defined as a representative of the artistic type. It would be expected that all, who have art as their profession, would belong to the artistic type. Nevertheless, within the boundaries of this category, clear disparities exist. It has been accepted [2] to separate these differences into three subcategories extremely artistic type (the most common in the artistic circles), medium subtype and thinking subtype. Pancho Vladigerov definitely belonged to the extremely artistic type.

The triumph of the direct impression not only in the works, but also in the life of Pancho Vladigerov can be clearly illustrated with the following amusing story - travelling with his moped, the renowned musician was hit by a motor rider, who immediately fled. The composer presented himself before the policeman, who shortly arrived running: "I am the people's artist professor Pancho Vladigerov, the one that wrote the Vardar Rhapsody", and for even greater authority he hummed the initial motive from the rhapsody, after which he explained what had happened to him. The policeman started questioning the professor, whether he had seen the number of the motorbike, what its model was, what the driver was wearing, but each time he received the answer "I don't know!". The policeman understandably concluded that it would be impossible to find the offender, since they knew nothing about him. Then "something flashes in the mind of the maestro and he spreads his arms: Wait, wait, pal, how come we don't know anything. The klaxon was in D sharp..." [3, p. 72] The composer thought that this impression, which bore meaning to him, should be a sufficient clue for the policeman and a sure lead (i.e. the assessment was not a result of the logical operations comparison and generalization, but was replaced by intuitively transferred importance).

Indicative for the belonging of the composer to the extremely artistic type is an interview, which he gave for the radio on the occasion that he had just written his symphonic suite for large orchestra, "Lyulin Impression", op. 63 - "... This is one lyrical painting with many dyes, with all the impressions of the night. With the sounds of people and birds, with the rustling of the trees and creeks. The third part is one "Traditional Celebration". A joyful horo builds the great culmination. The final is very cheerful and triumphant. [quote from 9, p. 249]. The author in fact stated that at the 
basis of the symphonic suite underlay specific impressions, sensations, and not generalizations. The musicologists Velenin Krastev commented on the second edition of the opera "Tzar Kalyon", including with the words: "Alien to any kind of rationality and contemplation, Vladigerov saturates the action with a rare expressivity. ... The national characteristic of the images is found" [10, p. $369-370]$. Stoyan Stoyanov spoke regarding the world-view of Vladigerov: "... one earthly, material perception of the world, filled with light and exuberance" [16, p. 9].

The powerful impressfulness of the painter - capturing and recreating as the most prominent characteristic of the perceived and painted with tones images, so the finest details, the incredible realism of the created musical characters, which makes them unquestionably recognizable, the bountifulness of the programme titles, suggesting a visual concreteness of the impressions-prototypes, proving the clear belonging of the tone artist to the extremely artistic type. Even the prevalence in his creative thinking of the mechanism of imagination, called "higher assessment" (usually more intuitive) over the other - anaxiomatization (requiring a greater awareness and argumentation of the artistic decision) - supports the statement that Pancho Vladigerov is a representative of the extremely creative type.

Another proof that Vladigerov belonged to the extremely creative type could be found, if we compare his approach to folk music, to the one of his colleague, contemporary and representative of the thinking subtype, Lyubomir Pipkov. In his piano cycles "Spring Vagaries", "Metrorhythmic Paintings and Studies" and "From 1 to 15" Pipkov created an organized "scheme" of the national Bulgarian meters, illustrating with musical pieces the most characteristic (the main meter of the piece) and the less common (usually appearing in the middle section, i.e. receiving the status of "supplements") variations of each meter. In his works, Vladigerov inweaved those meters, which he considered most closely related to the depicted musical character, the most attractive, most vital.

To the idea that the composer is a representative of the extremely artistic type, leads also the fact that some of his thoughts were not very successfully put into words, their meaning has to be felt intuitively, without seeking precision of expression. Such was the dedication, addressed to his student and colleague, the composer Nikolay Stoykov: "To my student, to remember his teacher" [17, p. 97] - short, inaccurate, but entirely intuitive, fatherly, warm!

\subsection{Low Anxiety}

Of the low anxiety of the composer, an indirect conclusion could be made on the basis of the optimism, characteristic for the personality and underlying the works of Vladigerov. On the subject of this optimism, which has saturated the works of the tone maestro, during a discussion about the newly written Fourth Concerto for Piano and Orchestra, in the Composers Union, Georgi Dimitrov - at the time director of the Direction of Musical Creation and Performer's Art at the Committee of Science, Arts and Culture, noted: "This piece, as well as most works by Pancho, carries a bright optimism, there is not one script, containing even a shade of doubt, of melancholy, Pancho is a creator of the vivid, of the joyful life" - quoted from [9, p. 194]. Similar is the opinion of the pianist, Konstantin Ganev: "... in his music, we would never hear even a hint of pessimism, hopelessness or powerlessness" [4, p. 22].

\subsection{Intelligence}

Explicitly characteristic of the intellectual qualities of Pancho Vladigerov is the high level of musical intelligence [a term of Howard Gardner - 5], the pronounced development of specific components of the bodily-kinesthetic one and the good state of interpersonal, to some degree at the expense of the mathematical and linguistic intelligence.

\subsubsection{Musical Intelligence}

Vladigerov possessed an absolute pitch [9], his timber and dynamic hearing also were of an enviable quality. As a conductor, as well as a composer, following closely the rehearsals of his works, he immediately and faultlessly recognized which instrumentalist of the orchestra played inaccurately and specifically which the false tone was (despite the rich colorful harmony, the thick texture and the large orchestra band, such as he often used). On a very high level was also his metrorhythmic sense, which gave him the opportunity to write down the musical score of folk songs in irregular meters and to compose complex in a metro-rhytmic sense pieces with capriciously changeable meters. In the piano piece "Rhytmic Movement" from "Watercolors" (op. 37), the approach polymetry can be found - in this case, the simultaneous appearance of an irregular (right hand) and regular (left hand) meter ${ }_{8}^{9}$. (Figure № 5).

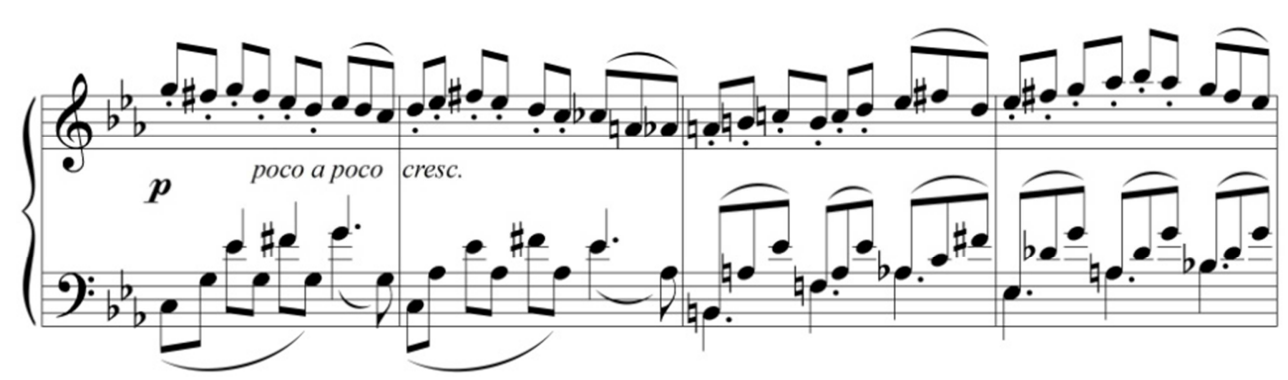

Figure № 5. "Rhytmic Movement", bars 49-52. 
The modal sense in Vladigerov was also sensitive, contributing to the multi-varied colourfulness of his works. For example the initial bars of "Autumn Elegy" have a Phrygian modal nuance (Figure № 6). Indicative of his auditory musical notions, was the following fact - the composer dreamt that he was conducting an orchestral work, based on an Old Jewish melody, which had been sung to him by his grandfather. The music became embedded in his consciousness and he wrote, as "in one breath" "Jewish Poem", op. 47 - [9, p. 180]. The famous musicologist and student of Vladigerov, Pencho Stoyanov, commented on the musical-auditory notions of his teacher with the words: "Vladigerov had the ability to decipher, to hear with his unique internal hearing the most complex and unknown of musical scores to find its most valuable qualities and its shortcomings with a striking ease and quickness" [15, p. 9]. The sense of multivoiceness was expressed clearly in the variedness and lavishness of his texture. The musicologists D. Hristov described the texture of Vladigerov's works in this way: "The simultaneous simplicity and the greatest complexity of the written on the note sheet texture, the thick and saturated timber realization with the highest ingenuity of the instrument combinations, intertwined together to a level of paradoxicality harmonic-functional moves, the incredible abundance of polyphonic voices..." [8, p. 11]. The construction of the musical contexture, of the texture in accordance with the requirements for depicting the personages, is also an indicator of a developed musical intelligence.

An element of the musical intelligence is also the sense of logical structure of the tonal thought, of musical form. Some of the works of Vladigerov have a very complex construction, but also accurately corresponding to the contents, embedded in it. The musicologist Pencho Stoyanov noted: "His ability to achieve a current, overflowing development in many cases overcomes the syntactic borders and especially in the rhapsodic examples (Two Paraphrases, op. 18, Improvisation, op. 36) the profile is far away from the traditional sectioning of the form. New planes appear, outlining different types of correlations, including such, which are close to the classical symmetry, and sometimes to the concentricity (Improvisation, op. 36)“ [14, p. 12].

Speaking of the highly developed musical intelligence of the composer is also the following: the beginning of the piano piece "Autumn Elegy" (Figure № 6) is built by: a pedal point on $\mathrm{g}^{1}$, a short melodic core $\left(\mathrm{g}^{1}-\mathrm{as}^{1}-\mathrm{g}^{1}\right)$ and several melodic constructions, whose diapason and duration gradually expand (which represents simultaneous expansion of the spatial and temporal limits of these structures).
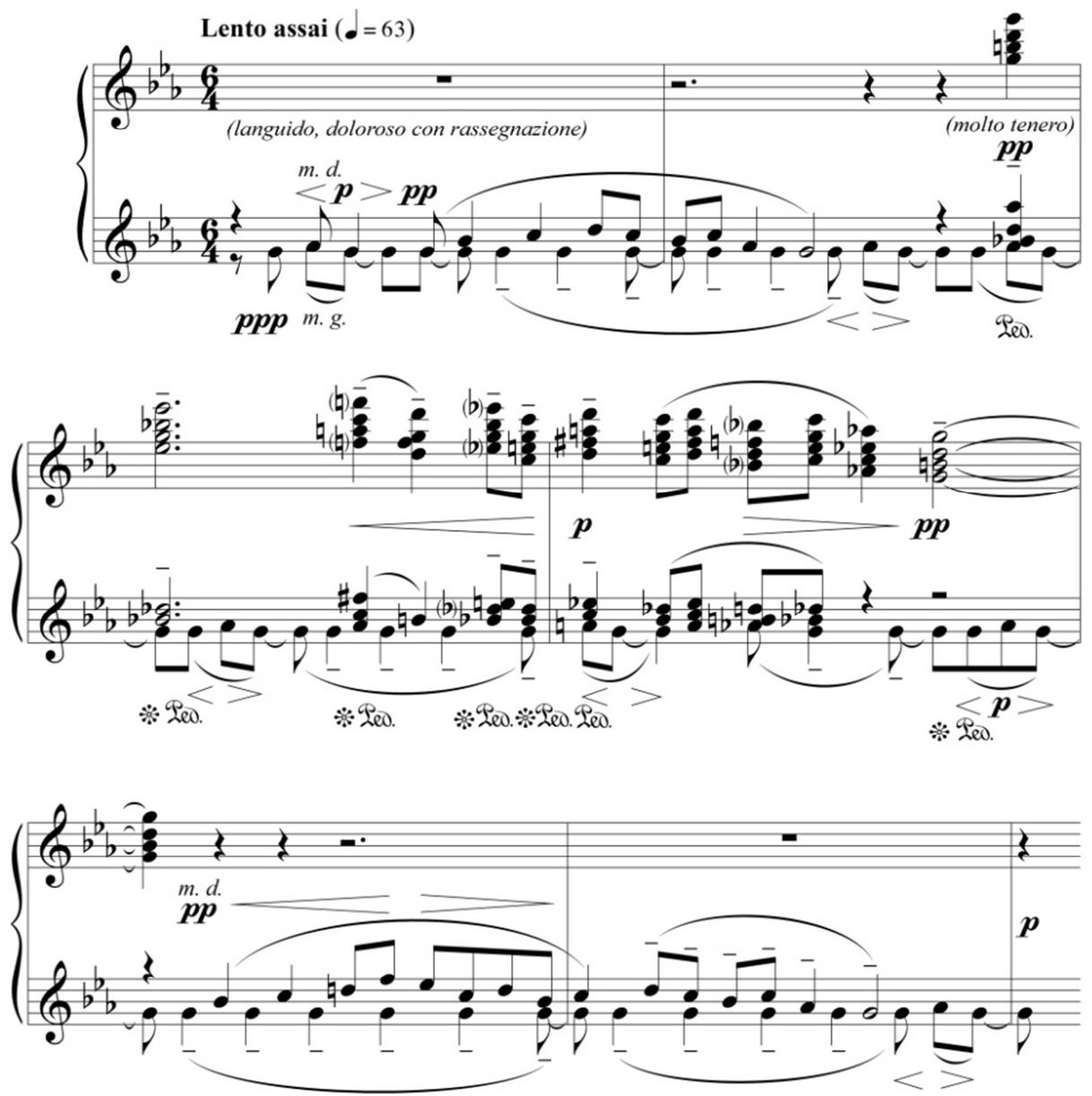

Figure № 6. "Autumn Elegy", op. 15, bars $1-7$. 
In this way of building the melodic constructs, the strong processes of activeness are prominent - expansion, development, spreading. The pedal point is an expression of the powerful processes of inactiveness, which retain, postpone in time the development of the activeness, during which tension is built, they "hold" on one and the same tone height the development of the lowest textural element. The multiple repetitions of the same melodic structure (the melodic core $g^{1}-a s^{1}-g^{1}$ ) is also an expression of a process of inactiveness. This "contradiction", collision of the two processes with an opposite sign, is experienced as sadness [2] Apart from this, the collision of the two processes, which initially has occurred in the nervous system of the composer, on its part, since with the resounding of the episode it has been reflected by the nervous system of the performer and the listener, creates in them the same feeling of despondency, of sadness. The contradiction of the two processes has another aspect, as well. The more varied melodic structures are further renewed, adding to them new motives, which is a manifestation of the activeness, while the pedal point and the short melodic core remain unchanged, which is a manifestation of inactiveness. The double contradiction enhances immensely the impact of the initial episode. As it was made clear by the quoted above statements by students of Pancho Vladigerov, who knew him well, the feelings like sadness, gloom, despair are not typical of the composer. The creation of such a deeply moving musical image is a manifestation of the incredibly precise and fine usage of the musical means of expression by the tone artist, of his highly developed musical intelligence, but also of the emotional intelligence, of the ability to embody and recreate even an artistic personage, which, by the common opinion of his acquaintances, is foreign to his own emotional character.

\subsubsection{Bodily-Kinesthetic Intelligence}

Evidence of the highly developed components of the bodily-kinesthetic intelligence in Pancho Vladigerov is his fame as a pianist, by far not just within the borders of Bulgaria - the first performer of almost all of his piano works, as well as his successful performances as an accompanist. Comments on his abilities have been made by: Evgeni Pavlov "... the man, whose jubilee we were celebrating, played so virtuously and passionately that the audience rose to their feet at the end and applauded frantically..." [9, p. 204] Boyan Lechev "... without preliminary preparation, he would play in a single breath works such as the sonata by Cesar Franck or whichever of Beethoven's or Brahm's sonatas" [11, p. 15]; Lybomir Dinolov (commenting the author's interpretations of Vladigerov): "His not too big hands grasped with agility the complex contexture of the piece. They were able to extract the characteristic Vladigerov piano sound - crystal clear and silvery sounding in the higher register of the grand piano, lusciously timbered and deeply chanting in the bass. The melodic gift of the composer has instilled in the performer the cantilena tone, which flows freely and markedly expressive... A paramount achievement in the performer's art of the composer Pancho Vladigerov is represented by his interpretations of the five grandiose concertos for piano and orchestra (the five piano concertos of P. Vladigerov - note by me - K.F.)... By their great in scope concept and virtuoso amplitude, the concertos of Vladigerov have common ground with the piano concertos of Rachmaninoff... The author's performances of Pancho Vladigerov have for us not just historical significance. They are praised for their high artistic importance, because they reflect the rich original gift of one great pianist talent" [9, p. 230-231]. On the subject of Vladigerov's clavier dexterity, the pianist Krasimir Gatev noted: "... his small, at first glance clumsy hands, marked with an incredible dexterity, simply, as a joke, overreached the lines of the fragment, on which we were working" [13, p. 39]. Stefan Ikonomov characterized his ability to read notes in the following way: "... he was unlike any other in his ability to read and play at first glance" $[13$, p. 35].

\subsubsection{Interpersonal Intelligence}

The good state of the interpersonal intelligence in Pancho Vladigerov was expressed in his communication with many and all kinds of different people, the maintaining of fruitful friendly relationships with some of the most prominent musicians - his contemporaries, of close contacts with his students, in the successful individual approach to each one, who was studying with him, as well as in his popular and often commented among Bulgarian musicians sense of humour. His student, the composer Lazar Nikolov, shared: "Rather too spontaneous in his reactions, he loved anecdotes and knew well how to create them" [13, p. 17]. Indeed, he created anecdotes even in moments, when he didn't feel much like laughing. This is made evident by the following story: while serving their military duty as guardsmen, the twin brothers Vladigerov had to ride horses. When the sergeant learnt that the two draftees were afraid, he ordered for the most temperamental horses in the division to be brought. The horse of Pancho Vladigerov started in an anxious trot. The rider "began to slide backwards and in the moment just before falling exclaimed:

"I reached the end of this horse, where's the other?" [3, p. 24]

The sense of humour has materialized in the works of Vladigerov through the writing of five humoresques, one grotesque, the piece "Laughter" and one scherzo (part of a string quartet). These pieces bear the fresh, original and vivid character of the humour of Vladigerov.

The developed interpersonal intelligence helped the prominent composer to train, to transfer his experience and knowledge to generations of composers. Among his students were famous Bulgarian tone artists like Vasil Kazandziev, Ivan Spasov, Konstantin Iliev, Lazar Nikolov, Alexandar Raychev, Pencho Stoyanov, Krasimir Kyurkchiyski, Milcho Leviev and many others. Vladigerov also taught piano. His interpersonal intelligence helped him develop a felicitous individual approach to each single student. This is 
acknowledged by his most prominent student in piano - the world famous Alexis Weissenberg: "He never imposed his personal view, but was able to put himself in the shoes of the student and to bring out all of his capabilities. Only the greatest of pedagogues could be able to work in this way with his students" [quote after 9, p. 186]. Similar is the opinion also of his biographer, E. Pavlov: "... in a completely personal, intuitive manner he found the way to the hearts of his students" [9, p. 187]. Vladigerov consulted many Bulgarian pianists, as well, who had not studied with him. They often went for advice to the distinguished composer and pianist, especially before performing one of his works in front of an audience.

\section{Conclusions}

1. The characteristics of the temperament of Vladigerov contribute to:

a) The great productivity of the author;

b) The manifold variety of genres and forms of his creations;

c) The long duration of some works, whose musical language however is devoid of any redundancy;

d) The brightfulness of many culminations;

e) The splendour of the musical contexture, the complex multi-voice, the polyphonic variety of the textural planes, as well as, again, the lack of any redundancy;

f) The abundance of author's prescriptions for agogic deviations, for frequent and quick switches in the dynamics;

g) The careful polishing of each detail, through which complex, but logically elegant musical structures are achieved;

h) The courage and self-confidence, combining the specific sounding of the Bulgarian folk music with the features of notation, characteristic for the Western-European tone art from the beginning of the 20th century, and becoming in this manner one of the creators of the national musical style, to defend these aesthetic positions of his.

2. The extraversion has significance for the direct, spontaneous character and intuitive accessibility of the opuses of Pancho Vladigerov.

3. The characteristic features of the imagination are connected to:

a) Presence of a large number of literally quoted folk songs;

b) Multiple author's transcriptions;

c) The combining of the valuable from the achievements of the national composers, who had worked before him, with contemporary musical language;

d) The brightly coloured multi-voiced texture, expressing wholly the national characteristic of his music.

4. The belonging to the extremely artistic type is reflected in the work of Vladigerov through:

a) The programme titles of many works;

b) The fine sense for accurate depiction of the musical personages;

c) The subordination of the means of expression to the specific creative purpose; d) The colourfulness and polychrome of harmony.

5. The low anxiety has left its mark on the character of the Vladigerov's music, painting it with mostly optimistic, joyful sounding.

6 . The vast practice of a concerto performing pianist has a relation to the virtuoso verve, the variedness of the clavier effects, the full manifestation of the capabilities of the piano instrument and the technical complexity, but also the comfort, the "piano-friendliness" of the piano works of Vladigerov.

7. The experience as a conductor contributes to:

a) The practical familiarization with every orchestra instrument and the particularities of its timber qualities;

b) The immense reserve of ideas for combinations of timbers and effects, which serve for a vivid and accurate sound depiction of the represented musical personage;

c) The susceptibility of the solo and chamber works to transcription for symphonic orchestra;

d) The symphonic sound of the opera and ballet music, observed and acclaimed by many critiques.

As it happens with many authors, who develop a new language of expression (Pancho Vladigerov was one of the creators and has an incredible contribution to the formation of the Bulgarian national musical language of expression), in a certain moment it turns out that they have created the new, the consecutive traditions, which the following generation of composers would chose to adopt, or to break.

\section{References}

[1] Angelov, A. Ivan Spasov - 60 Steps towards the Temple. Plovdiv, "Hermes", 1994 (Ангелов, А. Иван Спасов - 60 стъпки по пътя към Храма. изд. „Хермес” 1994)

[2] Blinova, M. - Musical Creativity and the Regularities of Higher Nervous Activity. Leningard, 1974 (Блинова, М. Музыкальное творчество и закономерности высшей нервной деятельности. Ленинград, 1974)

[3] Dimitrov, D. and Al. Vladigerov. The Smiles of Pancho Vladigerov. Plovdiv, "Hr. G. Danov", 1987 (Димитров, Д. и Ал. Владигеров. Усмивките на Панчо Владигеров. Пловдив, „Хр. Г. Данов“, 1987)

[4] Ganev, Konstantin. Some Characteristics of the Piano Style of Pancho Vladigerov. In: Bulgarian Music, issue 3/1974, p. 16-22 (Ганев, Константин. За някои черти от клавирния стил на Владигеров. В: сп. Българска музика, брой 3/1974, с. 16 - 22)

[5] Gardner, Howard. Intelligence reframed. Sofia, 2004 (Гарднър, Хауърд. Нова теория за интелигентността. Множествените интелигентности на 21. век. София, 2004)

[6] Goranova, Pravda. The Piano Concertos of Pancho Vladigerov. Interpretational Problems. In: Bulgarian Music, issue 3/1974, p. 36-39 (Горанова, Правда. Клавирните концерти на Панчо Владигеров. Интерпретационни проблеми. В: сп. Българска музика брой 3/1974, с. 36 - 39)

[7] Hills, P., Argyle, M. "Happiness, introversion-extraversion and happy introverts". In: Personality and Individual Differences, issue 30 (2001), p. 595-608. 
[8] Hristov, D. Our Teacher. In: Bulgarian Music, issue 3/1974, p. $10-12$ (Христов, Д. Нашият учител. В: Българска музика, бр. $3 / 1974$, с. $10-12)$

[9] Klosterman, Evgeni Pavlov. Pancho Vladigerov. Sofia, "Muzika", 2000 (Клостерман, Евгени Павлов. Панчо Владигеров. София, „Музика“ 2000)

[10] Krastev, Venelin. Articles on the History of Bulgarian Music. Sofia, "Muzika", 1977, 2nd ed., p. 369-373 (Кръстев, Венелин. Очерци по история на българската музика. София, „Музика“, 1977, II изд., с. 369 - 373)

[11] Lechev, Boyan. Statements and Memories on the Occasion of the Death of Pancho Vladigerov. In: Bulgarian Music, issue 9/1978, p. 14 - 16 (Лечев, Боян. Изказвания и спомени по повод смъртта на Панчо Владигеров. В: Българска музика, бр. $9 / 1978$, с. $14-16$ )

[12] Roset, Isaac. Psychology of Fantasy. Minsk, 1977 (Розет, Исак. Психология фантазии. Минск, 1977)

[13] Statements and Memories on the Ocasion of the 80th Anniversary of P. Vladigerov. In: Bulgarian Music, issue 3/1979, p. 11 - 53 (Изказвания и спомени по повод 80 годишнината на П. Владигеров. В: Българска музика, бр. 3/1979, c. 11 - 53)

[14] Stoyanov, Pencho. Compositional Problems in the
Instrumental Music of Vladigerov. In: Bulgarian Music, issue 3/1979, p. 11 - 15 (Стоянов, Пенчо. Композиционни проблеми в инструменталното творчество на Владигеров. В: Българска музика, бр. 3/1979, с. 11 - 15)

[15] Stoyanov, Pencho. Statements and Memories on the Occasion of the Death of Pancho Vladigerov. In: Bulgarian Music, issue 9/1978, p. 9 - 10 (Стоянов, Пенчо. Изказвания и спомени по повод смъртта на Панчо Владигеров. В: Българска музика, бр. 9/1978, с. 9 - 10)

[16] Stoyanov, Stoyan. A Classic of Bulgarian Music. In: Bulgarian Music, issue 3/1979, p. 4 - 9 (Стоянов, Стоян. Класик на българската музика. В: Българска музика, бр. 3/1979, с. 4 9)

[17] Stoykov, N. In Front of the Mirror. Plovdiv, "Zhanet 45", 2007 (Стойков, Н. Пред огледалото. Пловдив, „Жанет 45“, 2007)

[18] Tanev, Alexandar. Statements and Memories on the Occasion of the Death of Pancho Vladigerov. In: Bulgarian Music, issue 9/1978, p. 21 - 22 (Танев, Александър. Изказвания и спомени по повод смъртта на Панчо Владигеров. В: Българска музика, бр. 9/1978, с. 21 - 22)

[19] Travels, Encounters, Memories. In: Bulgarian Music, issue 3/1974, p. 10-1 (Пьтувания, срещи, спомени. В: сп. Българска музика, брой 3/март 1974, с. 10 - 15). 